\title{
Repeating the past
}

\author{
A lesson in family history.
}

\section{Peter Watts}

What you did to your uncle's grave was unforgivable.

Your mother blamed herself, as always. You didn't know what you were doing, she said. I could accept that when you traded the shofar I gave you for that eMotiv headset, perhaps, or even when you befriended those young toughs with the shaved heads and the filthy mouths. I would never have forgiven the swastika on your game pod but you are my daughter's son, not mine. Maybe it was only adolescent rebellion. How could you know, after all? How could any child really know, here in 2017? Genocide is far too monstrous a thing for history books and grainy old photographs to convey. You were not there; you could never understand.

We told ourselves you were a good boy at heart, that it was ancient history to you, abstract and unreal. Both of us doctors, familiar with the sad stereotype of the self-loathing Jew, we talked ourselves into treating you like some kind of victim. And then the police brought you back from the cemetery and you looked at us with those dull, indifferent eyes, and I stopped making excuses. It wasn't just your uncle's grave. You were spitting on six million others, and you knew, and it meant nothing.

Your mother cried for hours. Hadn't she shown you the old albums, the online archives, the family tree with so many branches hacked off mid-century? Hadn't we both tried to tell you the stories? I tried to comfort her. An impossible task, I said, explaining Never Again to someone whose only knowledge of murder is the score he racks up playing Zombie Hunter all day ...

And that was when I knew what to do.

I waited. A week, two, long enough to let you think I'd excused and forgiven as I always have. But I knew your weak spot. Nothing happens fast enough for you. These miraculous toys of yours - electrodes that read the emotions, take orders directly from the subconscious - they bore you now. You've seen the ads for Improved Reality $^{\mathrm{Tm}}$ : sensation planted directly into the brain! Throw away the goggles and earphones and the gloves, throw away the keys! Feel the breezes of fantasy worlds against your skin, smell the smoke of battle, taste the blood of your toy monsters, so easily killed! Immerse all your senses in the slaughter!

You were tired of playing with cartoons, and the new model wouldn't be out for so very long. You jumped at my third option. You know, your mother's working on something like that. It's medical, of course, but it works the same way. She might even have some sensory samplers loaded for testing purposes.

Maybe, if you promise not to tell, we could sneak you in ...

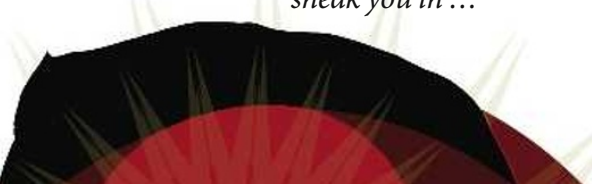

Not declarative ones, anyway.

But procedural memory? That I can do. The right frontal lobe, the hippocampus, basic fear and anxiety responses. The reptile is easily awakened. And you didn't need the details. No need to remember my baby sister face-down like a pile of sticks in the mud. No need for the colour of the sky that day, as I stood frozen and fearful of some real monster's notice should I go to her. You didn't need the actual lesson.

The moral would do.

Afterwards you sat up, confused, then disappointed, then resentful. "That was nothing! It didn't even work!" I needed no machines to see into your head then.

Senile old fart, doesn't know half as much as he thinks. And as one day went by, and another, I began to fear you were right.

But then came the retching sounds from behind the bathroom door. All those hours hidden away in your room, your game pod abandoned in the living room. And then your mother came to me, eyes brimming with worry: never seen you like this, she said. Jumping at shadows. Not sleeping at night. This morning she found you throwing clothes into your backpack - they're coming, they're coming, we gotta run - and when she asked who they were, you couldn't tell her.

So here we are. You huddle in the corner, your eyes black begging holes that can't stop moving, that see horrors in every shadow. Your fists bleed, nails gouging the palms. I remember, when I was your age. I cut myself to feel alive. Sometimes I still do. It never really stops.

Some day, your mother says, her machines will exorcise my demons. Doesn't she understand what a terrible mistake that would be? Doesn't history, once forgotten, repeat? Didn't even the worst president in history admit that memories belong to everyone?

I say nothing to you. We know each other now, so much deeper than words.

I have made you wise, grandson. I have shown you the world.

Now I will help you to live with it.

Peter Watts is a reformed marine biologist and failed gel-jock who is nevertheless adept at faking science, just so long as he can mix some characters and plot in among the numbers. His latest novel was nominated for several prestigious awards, winning none of them. 